servicemen is conducted. Concrete steps regarding the introduction of the institute of military clergy (chaplain service) in the Armed Forces of Ukraine dur-ing the formation of the Armed Forces of Ukraine during 1991-1994 were consi-dered and analyzed, as well as the most objectively covered processes that became the driving force during the formation and development of the military-religious relations in the outlined period.

On the basis of the historical facts analyzed, a model of meeting the reli-gious needs of servicemen in the period of formation and development of militaryreligious relations was established, as well as a system of education of servicemen in the Armed Forces of Ukraine and implementation of practical measures for organizing such work in the military environment.

Keywords: Ukrainian church, religious denominations, clergy, chaplains, spiritual education, pastoral care, cultural education, traditions, Ukrainian Orthodox Church of the Kiev Patriarchate, Ukrainian Orthodox Church of the Moscow Patriarchate, Ukrainian Greek Catholic Church. 
УДК - 355.233. 2 “1991 - 2018.”

DOI: 10.33099/2707-1383-2019-33-3-118-132

Кобзар А.О., кандидат історичних наук, дочент кафедри військової підготовки Національного університету оборони Украӥни імені Івана Черняховського (м. Київ);

Хабчук А.О., кандидат історичних наук, заступник начальника Житомирського військового інституту імені С.П. Корольова (м. Житомир);

Грицюк В.М., кандидат історичних наук, доцент, провідний науковий співробітник науково-дослідного иентту воєнної історії Національного університету оборони Украйни імені Івана Черняховського (м. Киї)

\section{МОРАЛЬНО-ПСИХОЛОГІЧНЕ ЗАБЕЗПЕЧЕННЯ У ЗБРОЙНИХ СИЛАХ УКРАЇНИ: ТРАНСФОРМАЦІЯ ТЕРМІНОЛОГІї (1991-2019)}

В статті розглядаються основні терміни та поняття морально-психологічного впливу, щьо визначали в 1991-2019 роках сутність, основні складові та напрями діяльності органів та посадових осіб структур морально-психологічного впливу в процесі їх становлення, розвитку та трансформації у Збройних Силах України. Увагу зосереджено на визначенні термінів та понять (дефініцій), їх роз'ясненні чи витлумаченні значення (сенсу). Подано також значення циих термінів і понять із англомовних джерел та джерел стандартів Організації Північноатлантичного договору (НАТО).

Ключові слова: особистість, сочіальне, мораль, психологія, моральнопсихологічний вплив, морально-психологічне забезпечення, виховна робота. 
Ретроспективний аналіз основних тенденцій розвитку структур морально-психологічного впливу в Збройних Силах України в період розбудови, реформування та будівництва Збройних Сил України, їх застосування в збройному конфлікті на Сході України, створення нової моделі Збройних Сил на сучасному етапі свідчить про те, що в повсякденній та бойовій діяльності військових організмів, діяльності структур морально-психологічного впливу міцно увійшли в ужиток значна кількість понять, термінів, дефініцій як суто морального так і психологічного значення, незважаючи на різні погляди і підходи до змісту і організації роботи у військах (силах) 3 морально-психологічної готовності до виконання завдань за призначенням та розвитку структур соціальнопсихологічної служби, виховної та соціально-психологічної роботи, виховної роботи, структур з гуманітарних питань та морально-психологічного забезпечення.

Проблематика формування та трансформації морально-психологічного забезпечення в українській історичній науці висвітлена недостатньо. Зокрема у науковому середовищі нема єдиної думки щодо розуміння сутності та змісту термінології моральнопсихологічного забезпечення.

Тому нами здійснено спробу ліквідувати прогалини у вітчизняній історичній науці стосовно трансформації термінологічного апарату предмету дослідження що і стало метою цієї статті. Актуальність вирішення поставленого завдання полягає у тому, що на теперішній час впровадження в діяльність Збройних Сил України військових стандартів НАТО вимагає уточнення понятійного апарату, вироблення єдиних поглядів щодо можливих форм і способів застосування (дій) підрозділів та військових частин Збройних Сил України.

Формування категорій стосовно МПЗ - складний і багатогранний процес, пов'язаний 3 тривалою теоретичною і практичною діяльністю. При цьому практика складає вихідний пункт, основу і мету їх створення. Загальні категорії мають відношення до всіх складових воєнного мистецтва. До них належать визначення таких понять, як збройні сили, збройна боротьба, стратегія, оперативне мистецтво, тактика тощо. До часткових категорій належать види воєнних дій, 
форми і способи застосування військ (сил) тощо.

Термін (від лат. terminus - межа, кордон) - слово або словосполучення, застосоване для позначення деякого поняття. Під терміном розуміється слово або словосполучення, яке $\epsilon$ назвою певного поняття, наприклад, оборона, наступ, форма, спосіб та ін. Отже, терміни “МПЗ” відноситься до часткових категорій воєнного мистецтва.

Визначення - це пояснення, яке розкриває сутність поняття. Як правило, пояснення формулюється у вигляді одного речення.

Поняття, концепт - форма мислення, яка відображає істотні властивості, зв'язки і відношення предметів і явищ в їхній суперечності і розвитку; думка або система думок, що узагальнює, виділяє предмети деякого класу за визначеними загальними і в сукупності специфічними для них ознаками.

Дефініція це стисле логічне визначення, яке містить у собі найістотніші ознаки визначуваного поняття [1].

Як було зазначено вище, на сьогодні за певних об'єктивних і суб'єктивних причин відсутні єдині визначення багатьох понять, категорій, термінів за проблематикою нашого дослідження. Об'єктивні причини, перш за все, пов'язані із швидкоплинними змінами сутності збройної боротьби, які дають поштовх розвитку теорії воєнного мистецтва. Саме iï розвиток зумовлює необхідність постійного уточнення змістовної частини багатьох понять, категорій, термінів, оскільки вони відображають найсуттєвіші сторони воєнного мистецтва як основної складової воєнної науки. Суб'єктивні причини, з одного боку, лежать у площині різного тлумачення військовими фахівцями об'єктивних процесів і явищ, що відбуваються з розвитком форм міжнародної миротворчої діяльності. 3 іншого боку, вони пов'язані 3 намаганням пристосувати застарілі поняття, категорії, терміни до нових умов або 3 необгрунтованим використанням термінологічного апарату, який використовується військовими фахівцями інших країн і не завжди відповідає стану розвитку вітчизняної військової справи.

При уточнені визначень термінів, які стосуються МПЗ участі ЗС України в операції Об'єднаних сил важливо 3 точки зору теорії воєнного мистецтва усвідомлювати, що військові частини 
(підрозділи) 3С України складають основу об'єднаних сил.

Складність наукового аналізу предмету статті полягає в тому, що категоріальний апарат, пов'язаний $з$ поняттям морально-психологічне забезпечення, здійснив значну еволюцію у хронологічних рамках дослідження.

Важливою складовою готовності та здатності військ (сил) до виконання поставлених завдань завжди був i $\epsilon$ високий моральний дух особового складу. Моральний дух — це духовна готовність і здатність військовослужбовців зносити випробування війни (бойових дій), труднощі військової служби, досягати перемоги над ворогом. Взаємопов'язаними сторонами морального духу військ (сил) $є$ морально-психологічний потенціал і морально-психологічний стан особового складу.

Морально-психологічний потенціал - це сукупність духовних можливостей особового складу, його свідомості, професійної підготовленості, які можуть стати фактором перемоги під час бою.

Морально-психологічний стан - це діюча частина морально-психологічного потенціалу, наявні духовні сили військовослужбовців, ступінь їх змобілізованості на виконання конкретної бойової задачі, морально-психологічний фактор досягнення перемоги.

Суспільство і держава на всіх історичних етапах розвитку цілеспрямовано впливали на свідомість та психіку військовослужбовця, морально-психологічний стан військового колективу та в цілому збройних сил. У різні часи цю діяльність визначали як “виховання”, “ідеологічну роботу”, “морально-політичну підготовку", “партійно-політичну роботу”, “політичну роботу в бойовій обстановці", “соціально-психологічну роботу”, “виховну роботу” тощо.

Від початку створення 3С України діяльність органів військового управління щодо реалізації морально-психологічного фактору при виконанні завдань здійснювалась на основі «Концепції соціально-психологічної служби ЗС України» (1991р.). 3 вересня 1998 року командири, начальники, офіцери виховних структур керувались вимогами «Концепції виховної роботи у Збройних Силах та інших військових формуваннях України» а з травня 1999 року — «Концепції морально-психологічного забезпечення 
підготовки та ведення операцій (бойових дій) Збройних Сил України».

Згодом морально-психологічне забезпечення як вид всебічного забезпечення визначено та нормативно закріплено у ряді керівних документів, які визначають порядок підготовки та застосування військ (сил) Збройних Сил України. Значною мірою вимоги до визначення категоріального апарату цього виду забезпечення були уточнені в 2007 році, та в період проведення АТО і ООС (2014-2019 роки).

На порядку денному вже давно стоїть питання інтеграції Збройних Сил України в Організацію Північноатлантичного договору. Досвід країн, які недавно вступили в Організацію Північноатлантичного договору показує, що для вступу потрібні не тільки політичні та економічні умови, а й суто військові. Однією із таких умов є військова стандартизація - діяльність, що полягає в установленні положень для загального та неодноразового використання щодо наявних чи потенційних завдань і спрямована на досягнення оптимального ступеня упорядкування у сфері оборони.

В зв'язку 3 прийняттям Закону України від 6 червня 2019 року №8370
"Про внесення змін до деяких законів України щодо військових стандартів" постає необхідність у введенні чи уточненні у Збройних Силах України термінів та понять, які б відповідали по змісту, корелювали з відповідними стандартами НАТО в гуманітарній сфері та в сфері морально-психологічного впливу.

Особистість - це сукупність індивідуальних соціальних іпсихологічних якостей, що характеризують людину і дозволяють їй активно і свідомо діяти; конкретна людина 3 погляду іiї культури, особливостей характеру, поведінки і т. ін.; індивідуальність, особа [2].

В кембріджському словнику [3]особистість (personality) розглядається як особливе поєднання якостей у людини, що робить цю людину відмінною від інших шляхом поведінки, почуттів та мисленням людини.

Особистість це відображення соціальної природи людини, розгляду iï як індивідуальності та суб'єкта соціокультурного життя, що розкривається в контекстах соціальних відносин, спілкування і предметної діяльності, соціально зумовлена система психічних якостей індивіда, що визначається залученістю людини до 
конкретних суспільних, культурних, історичних відносин.

Під “особистістю” розуміють стійку систему соціально значущих рис, що характеризують особу як члена того чи іншого суспільства або спільноти. Поняття «особистість» характеризує суспільну сутність людини, пов'язану із засвоєнням різноманітного виробничого і духовного досвіду суспільства.

Структура (від лат. Structūra “будова, пристрій; зв'язок або розташування складових частин") це сукупність стійких зв'язків частин об'єкта, що забезпечують його цілісність і тотожність самому собі, тобто збереження основних властивостей при різних зовнішніх і внутрішніх змінах. В словнику [4] структура (structure) визначається як розташування або організація деталей в системі. За своїм значенням термін “структура" в філософському сенсі відрізняється від слова "структура" в повсякденній мові й у ряді наук, де воно зазвичай означає "внутрішній устрій, будова". В англомовній літературі такому поняттю відповідає визначення інституція (institution) - організація, яка існує для того, щоб служити суспільним цілям [5].
Гуманітарний (франц. Ниmanitaire — від лат. Humanity - людська природа, освіченість) - це звернений до людської особистості, прав та інтересів людини, при цьому людина розглядається не як засіб, а як ціль суспільного розвитку. Такими є, наприклад, гуманітарні проблеми, гуманітарна допомога, гуманітарні науки. Гуманізм (humanism) в кембріджському словнику [6] - система думок і міркувань, заснована на людських цінностях та інтересах, часто не приймаючи переконань релігії.

Широкі кола українського суспільства не мають однозначного уявлення про зміст і соціальне значення понять гуманітарна сфера, гуманітарна політика. Такий стан пояснюється багатоманітністю питань, пов'язаних 3 гуманітарною складовою суспільного життя та їх тісним зв'язком із соціальними умовами.

Морально-психологічний вплив походить від понять “мораль” та “психологія”. Мораль - категорія філософії. Мораль (лат. moralis - моральний, від mores - звичаї) — це духовно-культурний механізм регуляції поведінки особистості та соціальних груп за допомогою уявлень про належне, в яких 
узагальнені норми, цінності, зразки поведінки, принципи ставлення до інших індивідів та соціальних груп. [7, с. 397-398 ]. В кембріджському словнику моральність (Morality) [8] визначається як особистий чи соціальний набір стандартів щодо доброї чи поганої поведінки та характеру, або якості правильності та чесності.

У сучасній філософській літературі під мораллю розуміється моральність, особлива форма суспільної свідомості і вид суспільних відносин; один з основних способів регуляції дій людини в суспільстві за допомогою норм. Мораль виникає і розвивається на основі потреби суспільства регулювати поводження людей у різних сферах їхнього життя. Мораль вважається одним із найдоступніших способів осмислення людьми складних процесів соціального буття. Корінною проблемою моралі $€$ регулювання взаємин і інтересів особистості і суспільства [9, с. 387-388]. Мораль завжди носить соціально-груповий характер: мораль сім’ї, мораль соціальної групи, класова мораль. Мораль нав’язується особистості ззовні у формі певних норм та правил. Оцінка моральної поведінки виходить із соціального оточення.
Моральні норми суспільства, які домінують у державі, втілюються в законодавчих актах. I моральні, і правові, і гуманітарні норми є соціальними. Спільним для них є те, що ці види слугують для регулювання і оцінки вчинків індивіда.

Отже, зафіксуємо: соціальне більш загальне ніж моральне та гуманітарне і включає в себе і моральні, правові та гуманітарні норми. Як відомо, оборона України, створені ЗС та IВФ України, вся їх повсякденна та бойова діяльність, військова служба базується в першу чергу на відповідних законах, норми поведінки військовослужбовців між собою та в колективах визначені також у законах (статутах) [10], наказах, настановах, інструкціях тощо.

Психологія - гуманітарна наука, (від грецького чvұи́ (psyché) - душа,


наука, що вивчає психічні явища (мислення, почуття, волю) та поведінку людини, пояснення якій знаходимо в цих явищах.

За півтора століття, 3 того часу як психологія почала самостійне існування, точаться суперечки щодо основних положень науки. Визначення їі пред- 
мету різними школами відображало не лише світоглядні, методологічні установки дослідників, але й носило ідеологічний характер, як у випадку 3 радянською наукою. Там психологія мусила боротись за виживання, адже визначення психіки як функції мозку було “затверджене та освячене” КПРС. Традиційно прикладною психологією називають галузі науки орієнтовані на застосування психологічних знань у конкретних сферах діяльності (політична, соціальна психологія, психологія війни, освіти, праці тощо); практична психологія — це галузь знань та досліджень щодо форм та методів використання психологічних знань фахівцями-психологами, та включає в себе психодіагностику, консультування, корекцію.

Соціальна психологія - розділ, галузь психології, яка займається вивченням закономірностей діяльності людини в умовах взаємодії в соціальних групах. Основні проблеми соціальної психології: закономірності спілкування та взаємодії людей, діяльність великих (нації, класи) і малих соціальних груп, соціалізація особистості та розвиток соціальних установок [11].
Соціальна психологія (Social psychology) [12] — наукове вивчення поведінки індивідів у їхній соціальній та культурній обстановці.

Вплив (Influence) - процес і наслідок зміни індивідом поведінки іншої людини, іiі намірів, уявлень, оцінок тощо в ході взаємодії з нею. В англійському словнику вплив - це сила змусити інших людей погоджуватися 3 вашою думкою або робити те, що ви хочете [13]. У виданні "Глосарій НАТО. Умови та визначення" [14] поняття розглядається як широкий спектр заходів, які підтримують та впливають на критичні ресурси шляхом навчання, консультування, наставництва або проведення комбінованих операцій.

Розрізняють прийоми впливу, які створюють та гальмують. Перші сприяють формуванню позитивних якостей, а другі - гальмують негативну поведінку. До прийомів, які створюють належать: переконання, моральна підтримка, організація успіху в діяльності, укріплення віри у власні сили, прохання, прояв довіри та уваги тощо. До гальмуючих - натяк, вияв засмучення, ласкавий докір, уявна байдужість або недовіра, організація природних наслідків. Найбільш 
ефективні прийоми непрямого впливу, які не викликають опору і впливають на підсвідомість через оточуюче середовище. Наприклад: іронія, різні види навіювання (авансування позитивних якостей, непряме прохання), “Я-повідомлення”, “Розрив стереотипу”, зміна діяльності тощо.

Соціа́ льне (лат. socialis — товариський, громадський) - одна з основних категорій соціології та соціальної філософії. Вперше вона була введена до наукового обігу К. Марксом для позначення характеристики однієї із сторін суспільного життя. Соціальне - це сукупність певних рис та особливостей суспільних відносин, інтегрована індивідами чи спільнотами у процесі спільної діяльності в конкретних умовах, яка виявляється в їхніх стосунках, ставленні до свого місця в суспільстві, соціальних явищ i процесів. Соціальне проявляється скрізь, де дія однієї людини зіставляється $з$ дією іншої.

За своїм змістом соціальне $є$ відображенням організації i життедіяльності суспільства як суб'єкта історичного процесу. Це інтегративне утворення, що акумулює знання, досвід, традиції та творчі здібності й ре- альну оцінку стану розвитку суспільства та його елементів. Воно виражає характер використання потенціалу i соціальних резервів суспільства, колективу, групи і особи для вироблення критеріїв оптимального розвитку всього соціального організму.

Соціальне може мати і позаособистісну форму буття. Наприклад, духовні і матеріальні цінності суспільства, груп, особистості; твори мистецтва і літератури й багато чого іншого, у яких втілено соціальну ідею людини як їхнього духовного творця. Категорія "соціальне" слугує, перш за все, для виявлення і відображення сутності суспільного життя людей; специфіки соціальної форми руху матерії, тобто відмінності суспільства від об’єднань тварин; суперечливої єдності людини як суспільної істоти i, разом з тим, біологічного організму; структури суспільних систем з погляду оптимізації їх функціонування і розвитку. Отже, категорія “соціальне” відображає і виражає специфіку буття суспільства як суб'єкта життєвого процесу в цілому, а відповідно - специфіку всіх соціальних процесів і соціальних суб'єктів.

Забезпечення - дія за значенням забезпечити; матеріальні засоби до 
існування [15]; а як визначає словник ні чи розумові зусилля, як правило, сучасних військово-політичних та для грошей [21].

військових термінів - це комплекс

Служба - дія за значенням слузаходів, що проводяться в інтересах підтримки військ (сил) в бойовій готовності, збереження їх бойової здатності та створення сприятливих умов для успішного i своєчасного виконання поставлених завдань [16]. Англомовне видання визначає забезпечення (provision) [17] як дію, коли ви надаєте щось, що комусь потрібно зараз або в майбутньому; ближче до розуміння терміну забезпечення поняття service (послуга), що визначається як державна система чи приватна організація, яка відповідає за певний вид діяльності, або за надання певної речі, яка потрібна людям [18], у ви- данні “ Глосарій НАТО. Умови та визначення" [19] поняття розглядається як процес, при якому збройні сили або їх частина приводяться до стану готовності до війни.

Робота — це дія за значенням робити; чиєсь виконання чого-небудь, чийсь труд, коло занять, обов'язків, те, чим зайнятий хто-небудь; справа, діло, те, що підлягає виконанню, здійсненню [20]. По-англійськи - діяльність, де людина використовує фізичжити; обов’язок, визначений посадою; перебування в армії, відбування військового обов'язку; певна галузь військових знань, обов'язків, а також система обслуговуючих установ у структурі армї [22]. Англомовне видання визначає військову службу (military service) [23] як систему, за якою кожен дорослий чоловік у країні повинен провести певний час в армії, флоті чи військово-повітряних силах.

В Україні необхідно розробити чіткий та прозорий механізм моніторингу процесу опрацювання та впровадження стандартів НАТО із реалістичними та досяжними цілями на коротку та середню перспективу, а також відмовитися від політизації питання "переходу" на стандарти НАТО.

Підсумовуючи розглянуті нами теоретико-методологічні підходи зауважимо, що питання морально-психологічного впливу на особовий склад Збройних Сил України пов’язані з різноманітними науками, такими як психологія, соціологія, політологія, етнографія, філологія та ін. Особливість застосування історичного методу 
дослідження полягає у розгляді всіх позиції усталеного їх розуміння, із заявищ і процесів у динаміці їх змін. лученням сучасних енциклопедичних

При викладенні основного матерісловників, енциклопедій (українські алу автори зробили спробу розкрити та англомовні видання), стандарту трансформацію понять пов'язаних 3680 / АAР-6, НАТО “Глосарій НАТО. 3 морально-психологічним забезпе- Умови та визначення" та практичного ченням впродовж 1991-2019 років. досвіду застосування. Автори не преОсновна увага зосереджувалася на тендують на вичерпність та запрошусутності, змісті, особливості осно- ють дослідників до конструктивної вних термінів, понять та дефініцій 3 критики та співпраці.

\section{Список використаних джерел і літератури}

1. Словник української мови: в 11 томах. — К.: Наукова думка, 19701980 pp. — [Електронний ресурс]. — Режим доступу: http://sum.in.ua/.

2. Там само.

3. Кембриджський словник - [Електронний ресурс]. - Режим доступу: https://dictionary.cambridge.org/dictionar.

4. Там само.

5. Там само.

6. Там само.

7. Філософський енциклопедичний словник. / Редакційна колегія. В. І. Шинкарук (голова редколегії), за заг. редакцією В. І. Шинкарука // К. : 2002 - 742 с.

8. Кембриджський словник - [Електронний ресурс]. - Режим доступу: https://dictionary.cambridge.org/dictionar.

9. Філософський енциклопедичний словник. / Редакційна колегія. В. І. Шинкарук (голова редколегії), за заг. редакцією В. І. Шинкарука // К. : $2002-742$ с.

10. Философский энциклопедический словарь / Гл. редакция: Л. Ф. Ильичев, П. Н. Федосеев, С. М. Ковалев, В. Г. Панов - М.: Сов. Энциклопедия, 1983. - $840 \mathrm{c}$. 
11. Соціальна психологія / Л. Орбан-Лембрик. - [Електронний ресурс]. Режим доступу: https://pidruchniki.com/1584072039084/psihologiya/.

12. Енциклопедія Британіка. - [Електронний ресурс]. - Режим доступу: www.britannica.com.

13. Словник сучасної англійської мови / Лонгман. - [Електронний ресурс]. — Режим доступу:[https://www.collinsdictionary.com/dictionary/english/ influence

14. Глосарій НАТО. Умови та визначення, аар-6, Видання 2018 р. - [Електронний ресурс]. - Режим доступу: http:// Stanag 3680/aap-6, nato glossary of terms and definitions.

15. Словник української мови: в 11 томах. — К.: Наукова думка, 1970-1980 pp.[Електронний ресурс]. — Режим доступу:http://sum.in.ua/.

16. Словник сучасних військово-політичних та військових термінів. [Електронний ресурс]. — Режим доступу: http://eu.prostir.ua/library/ 1974. html.

17. Кембриджський словник - [Електронний ресурс]. - Режим доступу: https://dictionary.cambridge.org/dictionar.

18. Там само.

19. NATO Glossary of terms and definitions (english and french) AAP-06 edition 2018 - [Електронний ресурс]. - Режим доступу: http:// Stanag 3680/aap-6, nato glossary of terms and definitions.

20. Словник української мови: в 11 томах. — К.: Наукова думка, 1970-1980 pp. [Електронний ресурс]. — Режим доступу:http://sum.in.ua/.

21. Кембриджський словник - [Електронний ресурс]. - Режим доступу: https://dictionary.cambridge.org/dictionar.

22. Словник української мови: в 11 томах. — К.: Наукова думка, 1970-1980 pp. [Електронний ресурс]. — Режим доступу:http://sum.in.ua/.

23. Словник сучасної англійської мови. Військові терміни. - [Електронний pecypc]. - Режим доступу: https://www.ldoceonline.com/dictionary/militaryservice. 


\section{References}

1. NATO Glossary of terms and definitions (english and french) AAP-06 edition 2018. — [Elektronnyi resurs]. — Rezhym dostupu: http:// Stanag 3680/aap-6, nato glossary of terms and definitions. [in English].

2. Entsyklopediia Brytanika. — [Elektronnyi resurs]. — Rezhym dostupu: www. britannica.com. [in Ukrainian].

3. Slovnyk suchasnykh viiskovo-politychnykh ta viiskovykh terminiv [Elektronnyi resurs]. — Rezhym dostupu: http://eu.prostir.ua/library/1974.html. [in Ukrainian].

4. Slovnyk suchasnoi anhliiskoi movy / Lonhman. - [Elektronnyi resurs]. Rezhym dostupu: [https://www.collinsdictionary.com/dictionary/english/influence [in Ukrainian].

5. Slovnyk ukrainskoi movy: v 11 tomakh. - K.: Naukova dumka, 19701980 rr.- [Elektronnyi resurs]. — Rezhym dostupu: http://sum.in.ua/. [in Ukrainian].

6. Slovnyk. Kolinz. / [Elektronnyi resurs]. — Rezhym dostupu: https://www. collinsdictionary.com/dictionary. [in Ukrainian].

7. Sotsialna psykholohiia / L. Orban-Lembryk. — [Elektronnyi resurs] — Rezhym dostupu: https://pidruchniki.com/1584072039084/psihologiya/. [in Ukrainian].

8. Fylosofskyi эntsyklopedycheskyi slovar / Hl. redaktsyia: L. F. Ylychev, P. N. Fedoseev, S. M. Kovalev, V. H. Panov - M.: Sov. Эntsyklopedyia, 1983. — 840 s. [in Russian].

9. Filosofskyi entsyklopedychnyi slovnyk. / Redaktsiina kolehiia. V.I. Shynkaruk (holova redkolehii), za zah. redaktsiieiu V.I. Shynkaruka // K. : 2002, 742 s. [in Ukrainian]. 
Kobzar A.O., Candidate of Historical Sciences, Associate Professor. $f$ Department of Military

Training of Ivan Chernyakhovsky National

Defence University of Ukraine (Kyiv);

Habchuk A.O., Candidate of Historical Sciences, Deputy Head of S.P. Koroleva Zhytomyr Military Institute (Zhytomyr);

Hrytsiuk V.M., Candidate of Historical Sciences, Associate Professor, Leading Researcher Research Centre of Military History of Ivan Cherniakhovskyi National Defence University of Ukraine (Kyiv)

\section{MORAL-PSYCHOLOGICAL PROVISION IN THE ARMED FORCES OF UKRAINE: TRANSFORMATION OF TERMINOLOGY (1991-2019)}

A retrospective analysis of the main trends in the development of structures of moral and psychological influence in the Armed Forces of Ukraine during the period of development, reformation and construction of the Armed Forces of Ukraine, their application in the armed conflict in eastern Ukraine, the creation of a new model of the Armed Forces at the present stage shows that in everyday life combat activities of military organisms, the activities of structures of moral and psychological influence are firmly in use a significant number of concepts, terms, definitions of both purely moral and psychological importance, despite different views and approaches to the content and organization of work in the troops (forces) on the moral and psychological readiness to perform tasks for the purpose and development of structures of social and psychological service, educational and socio-psychological work, educational work, structures on humanitarian issues and moral and psychological support. 